\title{
Phytochemical and Pharmacological Properties of Hertia L. Genus
}

\author{
Kaouther Majouli ${ }^{1^{*}}$, Malek Besbes Hlila ${ }^{2}$, Assia Hamdi ${ }^{3}$ and Abderraouf Kenani ${ }^{1}$ \\ ${ }^{1}$ Laboratory of Biochemistry, Research Unit: UR 12 ESO8 “Cell Signaling and Pathologies", Faculty of Medicine, \\ University of Monastir, Tunisia \\ ${ }^{2}$ Laboratory of Transmissible Diseases and of Biologically Active Substances, MDT01, Faculty of Pharmacy, \\ University of Monastir, Tunisia \\ ${ }^{3}$ Laboratory of Chemical, Galenic and Pharmacological Development of Drugs, Faculty of Pharmacy, University of \\ Monastir, Tunisia
}

Received: November 07, 2017; Accepted: January 02, 2018; Published: February 15, 2018

*Corresponding author: Kaouther Majouli, Laboratory of Biochemistry and Research Unit: UR 12ES08 "Cell Signaling and Pathologies", Faculty of Medicine, University of Monastir, Tunisia, E-mail: kaouther.bio@gmail.com

\section{Abstract}

The genus Hertia L. contains 12 species distributed all over south and North Africa and Southwest Asia. Some species of these plants are used traditionally for pain of stomach and to reduce hyperglycemia. It has been found that the species belonging to this genus possesses a rich phytochemical content and a wide range of pharmacological activities such as acaricidal, spasmolytic, anti-inflammatory, cytotoxic, anthelmintic, antibacterial, antioxidant effects and $\alpha$-glucosidase inhibition. In an aim to highlight the importance of Hertia, this study evaluated its phytochemical and pharmacological properties.
\end{abstract}

Keywords: Hertia; Phytochemistry; Pharmacology

\section{Introduction}

TNatural products, especially those of vegetable origin, have always been an important source of therapeutic agents. About 25$30 \%$ of all medicines available for the treatment of diseases are derived from natural products such as plants, animals, bacteria and fungi [1].

Due to the advance of synthetic chemistry, research on natural products in the pharmaceutical industry has experienced a decline. However, recent data from this industry show that, for some complex diseases, these natural products represent an extremely valuable source for the production of new chemical molecules because they represent privileged structures chosen by evolutionary mechanisms [2-4]. Medicinal plants have always had an important place in the therapeutic arsenal of humanity. According to the World Health Organization (WHO), about 65$80 \%$ of the world's population in developing countries, due to poverty and lack of access to modern medicine, rely heavily on traditional medicinal plants for their primary health care. Despite remarkable advances in synthetic organic chemistry in the twentieth century, more than $25 \%$ of the drugs prescribed in industrialized countries derive directly or indirectly their origins from the plants $[5,6]$.
In this context, and in view of the rapid disappearance of tropical forests and other important areas of vegetation, further research in the field of plants is desirable. Urgent attention should be given to as many species to determine their potential phytochemical and pharmacological properties and to evaluate their qualities. So, this green heritage represents an enormous reservoir of compounds waiting to be discovered [7].

Today, many studies carried out in the field of ethno pharmacology show that plants used in traditional medicine and which have been tested are often efficient plants in pharmacological models [8-10]. As a result, the chemical and biological studies are essential to characterize a medicinal plant.

This manuscript reviews the phytochemical, traditional use and pharmacological studies of the species belonging to the genus Hertia.

\section{Presentation of the genus Hertia}

In his "Elementa botanica," published in 1791, Necker divided the genus Othonna of Linnseus into two genres: Othonna and Hertia. According to this author, the Othonna has the naked clinanthe, the egret simple or null, and the periclin divided only at the summit, while Hertia has the clinanthe bristling with fimbrils, almost feathery egret and pericline deeply divided. But Necker found that the disc of calathide is also maleiflorous in both genres [11]. Jussieu et al. proposed another division of Othonna of Linnaeus into two genera, named Othonna and Euryops. This new division is based on the nature of the disc of calathide; it is masculiflora in Othonna and androgyniflora in Euryops. These authors have confirmed that Hertia is not really distinct from Othonna and that the characters exclusively attributed to each of them by Necker are inaccurate, because the characters of the one are often united in the same species with the Characters on the other.

The genus Hertia contains 12 species from Africa and Southwest Asia [12]. In Tunisia, there is only one species of this genus namely Hertia cheirifolia L. 


\section{Phytochemical and pharmacological study of the genus Hertia}

\section{Phytochemical study of the genus Hertia}

Previous chemical studies have been carried out on species of the genus Hertia and allowed the isolation of several chemical compounds. Indeed, five sesquiterpenes were isolated from the essential oils of the aerial part of the species Hertia intermedia namely, $\beta$-pinene, $\alpha$-pinene, $\alpha$-thujene, $\beta$-phellandrene and germacrene D [12]. Another similar study by Afsharypuor et al. [13] on the chemical composition of the aerial part of Hertia angustifolia showed that the same compounds were isolated from this plant.

Jakupovic et al. [14] carried out a study on the methanolic and chloroform extracts of the aerial part of H. pallens and the results showed that these extracts contained several sesquiterpenes, such as furoeremophilanes, eremophilanolides and germacrene D. The triterpenes were revealed in these extracts by the presence of oleanolic acid. Thus, the use of different polarity of solvents, followed by fractionation steps and the use of different chromatography techniques make it possible to separate and identify several chemical compounds present in the extracts of the plant $H$. cheirifolia. Indeed, previous chemical studies have revealed that the aerial part of this species is rich in eremophilenolides and steroids [15-18].

\section{Traditional use and pharmacological study of the genus Hertia}

Several species of the genus Hertia have been used in traditional medicine. In fact, women in Pakistan use the decoction of the leaves from H. intermedia to prevent abortion. Thus, regular consumption of this decoction is useful for all kinds of menstrual cycle problems. This decoction is also used for pain in the stomach. A pulp of ground leaves of $\mathrm{H}$. intermedia is also used as an external remedy for severe fever and for treating headaches [19].

In Tunisia, we investigated the traditional use of H. cheirifolia plant. The survey was conducted from August to October 2011 in the Haidra and Thala area, with 20 people aged 63 to 98 , with the aim of obtaining information on the parts, the method and the amounts used. In fact, old people use the infusion of the vegetative part (stems and leaves) of this plant to reduce hyperglycemia. Also, the pulp of crushed leaves is used against rheumatic pains and arthritis of the knee.

In order, to confirm the pharmacological effect of species of the genus Hertia, different activities have been demonstrated. Indeed, the essential oils of the aerial part of $H$. cheirifolia can provide a significant acaricidal activity with a concentration of $3.43 \mathrm{mg} / \mathrm{L}$ [20]. The chloroform extract of the aerial part from this species showed significant spasmolytic and anti-inflammatory effects [18].

Acetonic extracts of leaves from $\mathrm{H}$. intermedia and $\mathrm{H}$. pallens are endowed with cytotoxic activity (LC50 $=0.54 \mathrm{mg} / \mathrm{mL}$ ) $[21,22]$. An anthelmintic activity is recorded which $1 \mathrm{mg} / \mathrm{mL}$ of acetone extract from the leaves of $\mathrm{H}$. pallens can kill $20 \%$ of nematodes [22].

\section{Conclusion}

The phytochemical investigation of the genus Hertia shows that the species of Hertia are rich in terpenic compounds and endowed with important pharmacological properties. These species have variable phytochemical profiles which can possibly justify their bioactive potentials.

\section{Acknowledgement}

The authors acknowledge the Ministry of Higher Education, Scientific Research and Technology, Tunisia (Grant No. 11/TM06).

\section{References}

1. Newman DJ, Cragg GM, Snader KM. Natural products as sources of new drugs over the period 1981 to 2002. J Nat Prod. 2003;66(7):1022-1037.

2. Boldi AM. Libraries from natural product-like scaffolds. Curr Opin Chem Biol. 2004;8(3):281-286.

3. Clardy J, Walsh C. Lessons from natural molecules. Nature. 2004;432(7019):729-837.

4. Koehn FE, Carter GT. The evolving role of natural products in drug discovery. Nat Rev Drug Discov. 2005;4(3):206-220.

5. Calixto JB. Twenty-five years of research on medicinal plants in Latin America. J Ethnopharmacol. 2005;100(1-2):131-134.

6. Newman DJ, Cragg GM, Snader KM. The influence of natural products upon drug Discovery. Nat Prod Rep. 2000;17(3):215-234.

7. Marston ALM, Hosttemann K. Triterpenoid saponins from the roots of Silene Cucubalus. Fitoterapia. 2003;74(3):237-241.

8. Gurib-Fakim A. Medicinal plants: Traditions of yesterday and drugs of tomorrow. Mol Aspects Med. 2006;27(1):1-93.

9. Facchini PJ, De Luca V. Opium poppy and Madagascar periwinkle: model non-model systems to investigate alkaloid biosynthesis in plants. Plant J. 2008;54(4):763-784. doi: 10.1111/j.1365313X.2008.03438.X

10. Bhanot A, Sharma R, Noolvi MN. Natural sources as potential anticancer agents. Int J Phytomed. 2011;3(1):9-26.

11. Levrault FG. Dictionary of natural sciences. Strasbourg Paris. 1821.

12.Akhgar MR, Shariatifar M, Akhgar AR, Moradalizadeh M, FaghihiZarandi A. Chemical composition and antibacterial activity of the leaf essential oil from Hertia Intermedia. J Chem Nat Compd. 2012;48(2):329-331.

13.Afsharypuor S, Jahromy MM, Rahiminezhad MR. Investigation of the volatile oil of Hertia angustifolia (DC.) O.KUNTZE. J DARU. 2000;8(1-2):7-8.

14.Jakupovic J, Bohlmann F, Grenz M. Furoeremophilanes from Hertia Pallens. Phytochemistry. 1989;28(11):3231-3232.

15. Massiot G, Nuzillard JM, Men-Olivier LL, Aclinou P, Benkouider A, Khelifa A. Eremophilenolides from Hertia cheirifolia. Phytochemistry. 1990;29(7):2207-2210.

16. Aclinou P, Benkouider A, Massiot G, Men-Olivier LL. Eremophilenolides from Hertia cheirifolia. Phytochemistry. 1991;30(6):2083-2084. 
17. Aclinou P, Massiot G. Absolute configuration of eremophilenolides from Hertia Cheirifolia. Phytochemistry. 1993;34(3):859-860.

18. Ammar S, Edziri H, Mahjoub MA, Chatter R, Bouraoui A, Mighri Z. Spasmolytic and anti-inflammatory effects of constituents from Hertia cheirifolia. Phytomedicine. 2009;16(12):1156-1161. doi: 10.1016/j.phymed.2009.03.012

19. Tareen RB, Bibi T, Khan MA, Ahmad M, Zafar M. Indigenous knowledge of folk medicine by the women of Kalat and Khuzdar regions of Balochistan. Pak J Bot. 2010;42(3):1465-1485.
20.Attia S, Grissa KL, Mailleux AC, Heuskin S, Lognay G, Hance T. Acaricidal activities of Santolina africana and Hertia cheirifolia essential oils against the two-spotted spider mite (Tetranychus urticae). Pest Manag Sci. 2012;68(7):1069-1076. doi: 10.1002/ ps.3269

21. Esmaeili S, Hamzeloo-Moghadam M, Ghaffari S, Mosaddegh M. Cytotoxic activity screening of some medicinal plants from south of Iran. Res J Pharmacogn. 2014;1(4):19-25.

22. McGaw LJ, Eloff JN. Screening of 16 poisonous plants for antibacterial, anthelmintic and cytotoxic activity in vitro. S Afr J Bot. 2005;71(34):302-306. 